\title{
Anti-candidal activity of a novel peptide derived from human chromogranin $A$ and its mechanism of action against Candida krusei
}

\author{
RUI-FANG LI, XIAO-HUI YAN，YAN-BO LU，YA-LI LU，HUI-RU ZHANG, \\ SHI-HUA CHEN, SHUAI LIU and ZHI-FANG LU \\ College of Biological Engineering, Henan University of Technology, Zhengzhou, Henan 450001, P.R. China
}

Received January 14, 2014; Accepted August 13, 2015

DOI: $10.3892 / \mathrm{etm} .2015 .2731$

\begin{abstract}
Candida species (Candida spp.) are important fungal pathogens, which cause numerous clinical diseases associated with significant mortality and morbidity in healthcare settings. In our previous study, we identified a recombinant peptide, chromogranin A (CGA)-N46, corresponding to the N-terminal Pro31-Gln76 sequence of human CGA, that exhibited antifungal activity against Candida albicans. The present study investigated the antifungal activity of CGA-N46, and its underlying mechanism, against numerous Candida spp. CGA-N46 inhibited the growth of all of the tested Candida spp., of which Candida krusei exhibited the greatest sensitivity. CGA-N46 was able to disrupt the stability of the phospholipid monolayer without damaging the integrity and permeability of the outer membrane of $C$. krusei cells, and induced cytoplasm vacuolization and mitochondrial damage. In addition, treatment of $C$. kruse $i$ with CGA-N46 was associated with decreased levels of intracellular reactive oxygen species, a reduction in the mitochondrial membrane potential, and DNA synthesis inhibition. The results of the present study suggested that CGA-N46 was able to pass through the cell membrane of Candida spp. by temporarily destabilizing the phospholipid membrane, which in turn led to mitochondrial dysfunction and inhibition of DNA synthesis. Therefore, CGA-N46 may be considered a novel antifungal compound for the treatment of patients with $C$. krusei infections.
\end{abstract}

\section{Introduction}

Increasing numbers of immunocompromised patients has resulted in an increase in the incidence of fungal infections

Correspondence to: Professor Rui-Fang Li, College of Biological Engineering, Henan University of Technology, 100 Lianhua Street, Zhengzhou, Henan 450001, P.R. China

E-mail: 1rf@haut.edu.cn

Key words: human chromogranin A, CGA-N46, antifungal peptide, inhibition of DNA synthesis, mitochondrial membrane potential worldwide (1-3), of which the Candida species (Candida spp.) cause numerous clinical diseases associated with significant mortality and morbidity in healthcare settings (3-5). Candida albicans is the predominant pathogen of the Candida spp., which causes mucosal and invasive infections in humans $(3,6)$. However, numerous studies have reported that a growing number of infections can be attributed to non-albicans species $(4,5,7)$, many of which exhibit intrinsic resistance or reduced susceptibility to antifungal agents $(2,3,8)$. Among them, Candida krusei is an opportunistic fungal pathogen that exhibits intrinsic resistance to fluconazole $(3,9)$. Despite the low prevalence of C. krusei infections (accounting for 2-5\% of all yeast infections), the intrinsic resistance of the pathogen to fluconazole means that they are associated with the highest mortality rate $(30-60 \%)$ of all yeast $(2,3,10)$. Therefore, the discovery of antifungal compounds with novel modes of action that are effective against $C$. krusei infections, is critical.

Previous studies have indicated that antimicrobial peptides (AMPs) should be considered leading compounds in the development of novel antimicrobials (11-14). AMPs are produced by numerous species, in which they are important components of the innate immune system (15-17). The most significant feature of AMPs is their broad-spectrum activity against microbes, including those exhibiting multi-drug-resistance $(12,14,18)$. In addition, unlike traditional antibiotics that inhibit specific biosynthetic pathways, including cell wall or protein synthesis, the majority of AMPs conduct their respective functions by disrupting the membranes of microbes, resulting in the leakage of cell contents and cell death (12-14). Furthermore, the development of therapeutic AMPs may overcome the limitations associated with the current azoles.

In our previous study (19), we identified a novel antifungal peptide, chromogranin A (CGA)-N46, corresponding to the N-terminal Pro31-Gln76 sequence of human CGA, which exhibited antifungal activity against $C$. albicans. CGA is a soluble protein that is present in the majority of endocrine cells and neurons (20-23). The endogenous CGA-derived peptides, including vasostatin-I and catestatin, have natural defensive roles in the human body (24-26), and have been shown to possess antifungal activity; for instance, vasostatin-I (CGA1-76), an $\mathrm{N}$-terminal fragment of CGA, was able to kill numerous fungal and yeast cells in the micromolar concentration range (23). In 
addition, Lugardon et al (27) synthesized numerous derived CGA N-terminal fragments, and demonstrated potent antifungal activity for the shortest peptide, which corresponded to the sequence Arg47-Leu66 and was named chromofungin. Subsequently, it was proposed that destabilization of the fungal cell wall and plasma membrane, alongside intracellular inhibition of calmodulin-dependent enzymes, may be the underlying mechanism by which vasostatin-I and chromofungin inhibit fungal growth (27).

In a related study, vasostatin-I engaged in electrostatic, as well as hydrophobic, interactions with the membrane phospholipids of fungi under physiological conditions, and was demonstrated to enhance the fluidity of saturated species of phosphatidylserine (28), suggesting numerous mechanisms by which vasostatin-I may inhibit fungal growth. Concordantly, numerous AMPs have been shown to exert their effects on various fungal targets $(29,30)$.

The authors of the present study hypothesized that the underlying antifungal mechanism of the CGA N-terminal fragment may not be limited to mechanisms previously demonstrated for other AMPs. In our previous study (31), we expressed numerous recombinant derived peptides of the CGA $\mathrm{N}$-terminus in order to elucidate the underlying antifungal mechanism of the CGA N-terminal fragment. The results suggested that the short CGA-N46 peptide, corresponding to the sequence Pro31-Gln76, possessed antifungal activity against numerous Candida spp., of which $C$. kruse $i$ was the most sensitive strain. The secondary structure of CGA-N46 was predicted to be an $\alpha$-helix by the bioinformatic software ScanProsite (http://www.expasy.org/tools/scanprosite), and its isoelectric point was 7.38. As a hydrophilic protein, it had no transmembrane domain. In the present study, the mechanisms of action of CGA-N46 AMP against C. kruse $i$ were studied.

\section{Materials and methods}

Reagents. Triton X-100, and the fluorescent stains propidium iodide (PI), 2',7'-dichlorofluorescin diacetate (DCFH-DA) and Rhodamine-123 (Rh-123) were purchased from Sigma-Aldrich (St. Louis, MO, USA). All of the other reagents were of the highest purity available from commercial sources, and all of the solvents were of high-performance liquid chromatography grade. The water used for all experiments was supplied by a Milli- ${ }^{\circledR}$ Water Purification system (Merck Millipore, Beijing, China). Candida krusei ATCC 6258 was supplied by the Chinese Academy of Medical Sciences and Peking Union Medical College (Beijing, China). The yeast cells were grown overnight in liquid Sabouraud medium (SD; Difco, BD Biosciences, San Jose, CA, USA), at $30^{\circ} \mathrm{C}$ with agitation.

Antifungal assay. The minimum inhibitory concentrations (MICs) of CGA-N46 against five different Candida strains (C. glabrata, C. parapsilosis, C. krusei, C. tropicalis, and $C$. albicans) were determined using the Clinical and Laboratory Standards Institute M-27A3 methodology $(32,33)$. All strains were obtained from American Type Culture Collection (Manassas, VA, USA). CGA-N46 was prepared and stored in our laboratory, then serially diluted in $20 \mathrm{mM}$ phosphate-buffered saline (PBS; pH 6.0) to a final concentration range of $0.62 \mu \mathrm{M}-3.2 \mathrm{mM}$. C. krusei cultures that had not been treated with CGA-N46, or incubated in SD, were employed as positive and negative controls, respectively. Each experiment was repeated three times.

Transmission electron microscopy (TEM). The effects of CGA-N46 on C. krusei morphology and internal organelles were investigated using TEM. Briefly, mid-log phase $C$. krusei cell pellets were washed with $20 \mathrm{mM}$ PBS (pH 6.0), and resuspended to a concentration of $10^{6} \mathrm{CFU} / \mathrm{ml}$ in SD. Subsequently, the cell suspension was incubated with CGA-N46, at a concentration of $0.8 \mathrm{mM}$ at $30^{\circ} \mathrm{C}$ for $3 \mathrm{~h}$, followed by washing with PBS. Fungal pellets were fixed in $500 \mu 12.5 \%$ glutaraldehyde in PBS at $4^{\circ} \mathrm{C}$ overnight, and then further fixed with $1 \mathrm{ml} 4 \%$ potassium permanganate for $30 \mathrm{~min}$ at room temperature. After being washed and re-suspended in $1 \mathrm{ml}$ saturated uranyl acetate for $30 \mathrm{~min}$ at room temperature, the samples were dehydrated in ascending concentrations of acetone 2 times per concentration for 5 min each (30, 50, 70 and 95\%), and further dehydrated in absolute acetone 5 times for 15 min each. Subsequently, the pellets were gently stirred in a 1:1 mixture of absolute acetone and final Spurr resin (Polysciences, Inc., Warrington, PA, USA) for $1 \mathrm{~h}$ at room temperature. Then, the pellets were transferred to a 1:3 mixture of absolute acetone and Spurr resin for $3 \mathrm{~h}$, and subsequently to Spurr resin alone overnight. Specimens were subsequently embedded in gelatin capsules and heated at $70^{\circ} \mathrm{C}$ for $9 \mathrm{~h}$ to polymerize. Ultra-thin sections, obtained using an Ultracut E ultramicrotome (Reichert-Jung, Inc., Austria), were stained with uranyl acetate, followed by staining with lead citrate. The specimens were observed using a transmission electron microscope (Hitachi H-7650; Hitachi, Ltd., Tokyo, Japan). C. krusei cells that had not undergone CGA-N46 treatment were used as a control.

Langmuir-Blodgett experiment. To determine the effects of CGA-N46 on the stability of the phospholipid monolayer of fungal cells, the variability of the surface pressure $(\pi)$ versus the mean molecular area $(\mathrm{A})$ isotherms was investigated using a modified Langmuir Blodgett procedure (34). Briefly, CGA-N46 was dissolved in double distilled $\mathrm{H}_{2} \mathrm{O}$ to $0,0.2,0.8$ and $1.6 \mathrm{mM}$ solutions, which were used as the sub-phase. Phospholipids in ethyl ether ( $40 \mu \mathrm{l}$ of $0.32 \mathrm{mg} / \mathrm{ml}$ ) were spread on the sub-phase surface with a Hamilton microliter syringe, and were left standing for $15 \mathrm{~min}$ to allow complete evaporation of the solvent. Subsequently, the floating monolayer was compressed continuously with a linear movement of two barriers at $2 \mathrm{~mm} / \mathrm{min}$. The $\pi$-A isotherms were measured on a KSV Minitrough Langmuir-Blodgett system (KSV Instruments, Helsinki, Finland), operated using a Wilhelmy platinum plate with a dynamic surface pressure range of $0-40 \mathrm{mN} / \mathrm{m}$, and a resolution of $4 \mu \mathrm{N} / \mathrm{m}$. The sub-phase temperature was maintained within $20.0 \pm 0.5^{\circ} \mathrm{C}$ using a thermostatic bath. The trough and barriers were thoroughly cleaned using $95 \%$ ethanol and hot water between each isotherm, and every $\pi$-A isotherm was repeated $\geq 3$ times, in order to ensure reliable results. Double distilled $\mathrm{H}_{2} \mathrm{O}$ was used as the control.

Permeability of the outer membrane. Membrane permeability was determined by the uptake of PI, a high affinity nuclear stain that penetrates compromised cell membranes and fluoresces upon binding to nucleic acids, using the method 
outlined in Lv et al (14), with minor alterations. Briefly, an overnight culture of $C$. krusei in SD broth was washed once and resuspended to $10^{6} \mathrm{CFU} / \mathrm{ml}$ in SD broth. CGA-N46 (0, 0.4 or $0.8 \mathrm{mM}$ ) was added to the $C$. krusei cells, and incubated at $28^{\circ} \mathrm{C}$ for $3 \mathrm{~h}$. Subsequently, the cells were washed in PBS and resuspended in SD, after which they were incubated with $50 \mu \mathrm{g} / \mathrm{ml} \mathrm{PI}$ in the dark at $37^{\circ} \mathrm{C}$ for $10 \mathrm{~min}$. The fluorescence images were observed using a fluorescent microscope (Eclipse TS100; Nikon Corporation, Tokyo, Japan), with an excitation wavelength of $488 \mathrm{~nm}$. C. krusei cells that had not undergone treatment with CGA-N46, or were treated with $0.3 \%$ Triton-X100, were used as negative and positive controls, respectively.

Measurement of levels of reactive oxygen species (ROS). The levels of ROS were determined using the fluorescent dye DCFH-DA as a reference (35). Intracellular $\mathrm{H}_{2} \mathrm{O}_{2}$ or low molecular weight peroxides are able to oxidize DCFH-DA to the highly fluorescent compound dichlorofluorescein (DCF). Briefly, mid-log phase $C$. kruse $i$ cells were prepared at a density of $10^{7} \mathrm{CFU} / \mathrm{ml}$ and treated with CGA-N46 (0, 0.2, 0.4 or $0.8 \mathrm{mM}$ ) for $3 \mathrm{~h}$ at $30^{\circ} \mathrm{C}$. Subsequently, cells were washed with PBS and resuspended in SD, after which DCFH-DA (final concentration, $10 \mu \mathrm{M}$ ) was added to the cell suspensions in the dark for $20 \mathrm{~min}$ at room temperature. DCF fluorescence was measured using laser scanning confocal microscopy (LSM 710; Zeiss, Oberkochen, Germany), at an excitation wavelength of $488 \mathrm{~nm}$ and an emission wavelength of $535 \mathrm{~nm}$. C. krusei cells that had not undergone treatment with CGA-N46, were used as a control.

Measurement of the mitochondrial membrane potential. The mitochondrial membrane potential was assessed using a fluorescent probe, Rh-123. Briefly, mid-log phase C. krusei cells at a density of $10^{7} \mathrm{CFU} / \mathrm{ml}$ in $20 \mathrm{mM}$ PBS (pH 6.0), were treated with CGA-N46 $(0,0.2,0.4$ or $0.8 \mathrm{mM})$ for $3 \mathrm{~h}$ at $30^{\circ} \mathrm{C}$. After cells were washed and resuspended in SD, Rh-123 (final concentration, $10 \mu \mathrm{g} / \mathrm{ml}$ ) was added to the cell suspensions in the dark for $30 \mathrm{~min}$ at room temperature. The fluorescence images were observed using a fluorescent microscope (Eclipse TS100, Nikon Corporation), at an excitation wavelength of $507 \mathrm{~nm}$ and an emission wavelength of $529 \mathrm{~nm}$.

Analysis of in vitro DNA synthesis. Polymerase chain reaction (PCR) assays were used to evaluate the effects of CGA-N46 on DNA synthesis in vitro. PCR was conducted according to the method outlined in Sambrook et al (36), using reagents purchases from (Sigma-Aldrich). Briefly, $3 \mu 1$ 10X PCR buffer was mixed with $2.4 \mu 125 \mathrm{mM} \mathrm{MgCl}_{2}, 0.6 \mu 110 \mathrm{mM}$ deoxyribonucleoside triphosphates (dNTPs) mixture, $1.5 \mu \mathrm{l}$ $20 \mu \mathrm{M}$ upstream primer, $1.5 \mu \mathrm{l} 20 \mu \mathrm{M}$ downstream primer of the desired gene cga-N46, and $0.3 \mu \mathrm{l} \mathrm{PCR}$ template $(2 \mathrm{ng} / \mu \mathrm{l}$ plasmid pSVTQ, which bore the cga-N46 gene). Primers were synthesized by Sangon Biotech Co., Ltd. (Shanghai, China), and their sequences were as follows: Upstream, 5'-AACCC ATGCCTGTCAGCAAC-3' and downstream, 5'-ATGTGC CCTCTC-3'. In order to test the effects of CGA-N46 on the Taq DNA polymerase, $0.15 \mu \mathrm{l}$ Taq DNA polymerase (5 U/ $\mu \mathrm{l})$ was treated with $21 \mu \mathrm{l} 0.4 \mathrm{mM}$ CGA-N46 in $20 \mathrm{mM}$ PBS (pH 6.0) for $30 \mathrm{~min}$ at $37^{\circ} \mathrm{C}$, prior to addition into the PCR
Table I. MIC of CGA-N46 against Candida species.

\begin{tabular}{lc}
\hline Strains & MICs (mM) \\
\hline Candida glabrata & 0.8 \\
Candida parapsilosis & 0.8 \\
Candida krusei & 0.1 \\
Candida tropicalis & 0.2 \\
Candida albicans & 0.2 \\
\hline
\end{tabular}

MIC, minimum inhibitory concentration; CGA, chromogranin A.

mixture. The same treatment of the Taq DNA polymerase in the absence of CGA-N46 was used as a positive control, and $21 \mu 120$ mM PBS (pH 6.0) without Taq DNA Polymerase was used as the negative control. A final control was the same reactions without the incubation at $37^{\circ} \mathrm{C}$ for $30 \mathrm{~min}$. PCR was conducted in an S1000 thermal cycler (Bio-Rad Laboratories, Inc., Hercules, CA, USA) using the following parameters: $95^{\circ} \mathrm{C}$ for $5 \mathrm{~min}$, followed by 30 cycles of $95^{\circ} \mathrm{C}$ denaturation for 1 min, $58^{\circ} \mathrm{C}$ annealing for $30 \mathrm{sec}, 72^{\circ} \mathrm{C}$ extension for $1 \mathrm{~min}$, and a final extension at $72^{\circ} \mathrm{C}$ for $10 \mathrm{~min}$. PCR products $(10 \mu \mathrm{l})$ were separated using $1 \%$ agarose gel electrophoresis.

Flow cytometry. Mid-log phase $C$. krusei cells $\left(1 \times 10^{6} \mathrm{CFU} / \mathrm{ml}\right)$, incubated with $0.8 \mathrm{mM}$ CGA-N46 in $20 \mathrm{mM}$ PBS (pH 6.0), were incubated for 12,24 and $48 \mathrm{~h}$ at $30^{\circ} \mathrm{C}$, with agitation. Subsequently, the cells were collected, washed, resuspended and fixed in $70 \%$ ice cold ethanol for $24 \mathrm{~h}$. The fixed cells were then incubated with the PI solution (50 $\mu \mathrm{g} / \mathrm{ml} \mathrm{PI,} 100 \mu \mathrm{g} / \mathrm{ml}$ RNase (Sangon Biotech Co., Ltd.), and 0.2\% Triton X-100 supplemented with PBS) for $30 \mathrm{~min}$ in the dark. Cell cycle distribution analysis was performed using the Cell Quest Flow Cytometer (FACScalibur; BD Biosciences), and the results were analyzed using the modFit LT $^{\mathrm{TM}}$ software, version 3.1 (Verity Software House, Topsham, ME, USA).

Statistical analysis. Experimental data were analyzed using the PASW Statistics software, version 18 (SPSS, Inc., Chicago, IL, USA) to perform one-way analysis of variance followed by Least Significant Difference and Duncan's tests. The results are reported as the mean \pm standard error of the mean. Differences between the treatment and control groups were considered to be statistically significant at $\mathrm{P}<0.05$, and highly significant at $\mathrm{P}<0.01$.

\section{Results}

Anti-candidal activity. The MIC of CGA-N46 against numerous Candida spp. (Table I) was used as an indicator of the peptide's anti-candidal activity. CGA-N46 was active against all of the yeasts tested (MICs, 0.1-0.8 mM), with C. krusei exhibiting the greatest sensitivity (MIC, $0.1 \mathrm{mM}$ ).

Effects of CGA-N46 on cell morphology. The effects of CGA-N46 on the cellular morphology and organelles of C. krusei were investigated using TEM. As compared with the control (Fig. 1A), the cell wall and outer membrane were 

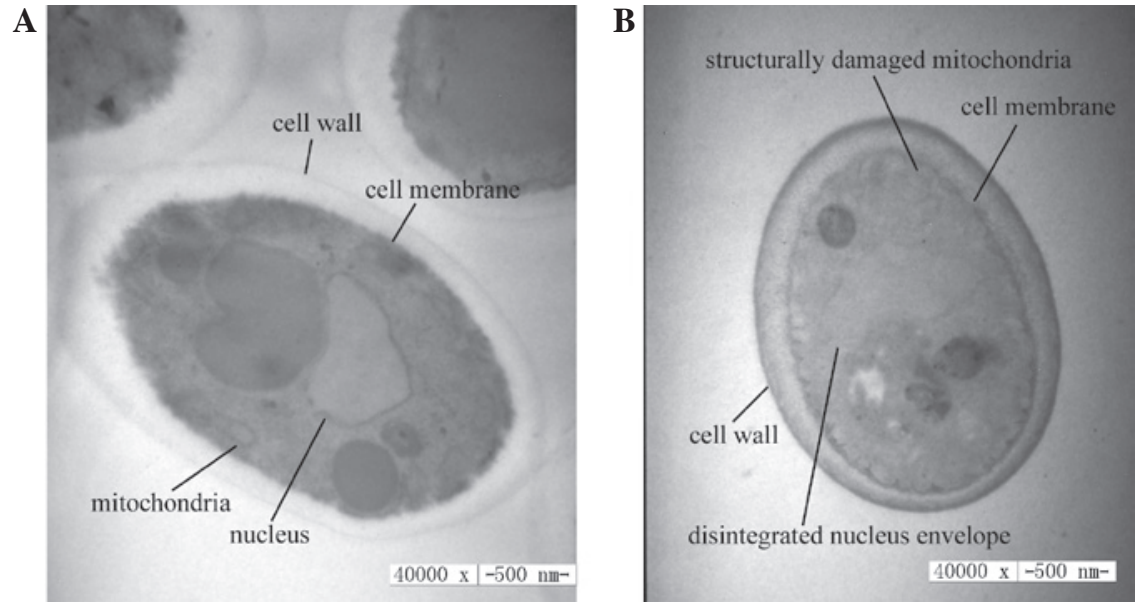

Figure 1. Transmission electron microscopy micrographs of Candida krusei cells. (A) Control cells; and (B) C. krusei cells treated with $0.8 \mathrm{mM}$ chromogranin A-N46 for $3 \mathrm{~h}$ at $30^{\circ} \mathrm{C}$.

clear in CGA-N46-treated C. krusei cells, but significant cytoplasmic vacuolization was observed. Furthermore, mitochondrial structural damage was observed, and the integrity of the nuclear envelope was disrupted, as demonstrated by the visible pores (Fig. 1B). These results suggest that CGA-N46 may penetrate the cell membrane and subsequently interact with cellular organelles.

Effects of CGA-N46 on the stability of the phospholipid monolayer. The effects of CGA-N46 on the stability of the cell membrane were demonstrated by the variability of the $\pi-A$ isotherms of the phospholipid monolayer (Fig. 2). The limiting area of the phospholipid monolayer was estimated by extrapolating the straight portion of the $\pi$-A isotherm to zero surface pressure. As compared with the control, CGA-N46-treatment $(0,0.4,0.8$ or $1.6 \mathrm{mM})$ was associated with marked alterations to the shape of the $\pi$-A isotherms. As the concentration of CGA-N46 in the sub-phase increased, the mean molecular areas increased, which suggests that CGA-N46 was able to lower the density of phospholipids in the lipid monolayer. This indicates that CGA-N46 treatment may promote disorder of membrane phospholipids, leading to a reduction in membrane stability.

Effects of CGA-N46 on the outer membrane permeability of C. krusei cells. The PI uptake assay was used to detect the effects of CGA-N46 on the permeability of the outer membrane of $C$. krusei cells. PI is a small hydrophobic molecule that fluoresces weakly in aqueous solution but strongly when it enters a hydrophobic environment, including a biomembrane; therefore, PI is widely used to detect the disruption of the outer membrane of microbes. The PI fluorescent probe was unable to enter the outer membrane of $C$. krusei cells following treatment with CGA-N46 (0.4 or $0.8 \mathrm{mM}$; Fig. 3). This result suggests that CGA-N46 does not affect the permeability of the outer membrane of $C$. krusei cells.

Effects of CGA-N46 on ROS levels. To investigate the effects of CGA-N46 on intracellular ROS levels, the $C$. krusei cells were treated with CGA-N46 $(0,0.2,0.4$ or $0.8 \mathrm{mM})$ for $3 \mathrm{~h}$ at $30^{\circ} \mathrm{C}$. Intracellular ROS oxidize DCFH-DA to the highly fluorescent

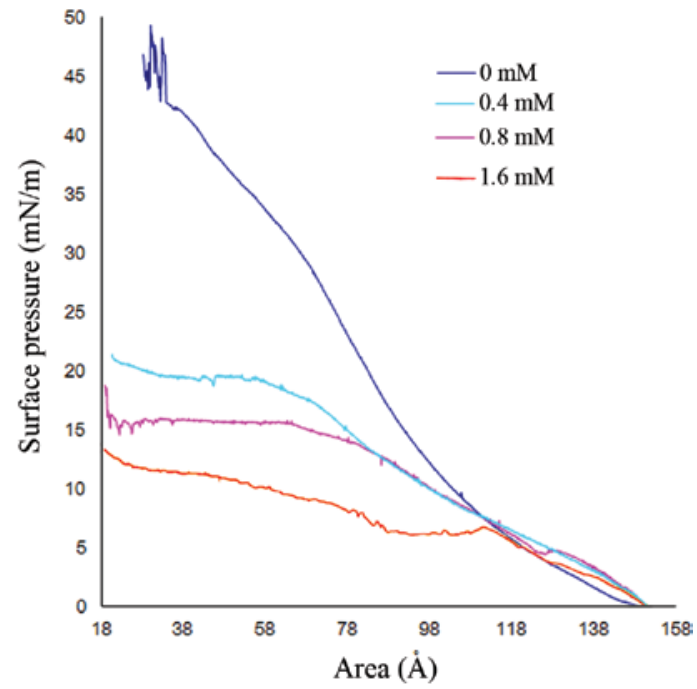

Figure 2. Effects of chromogranin A (CGA)-N46 on the stability of the phospholipid monolayer. The variability of the surface-area $(\pi-\mathrm{A})$ isotherms of the phospholipid monolayer, following treatment with various concentrations of CGA-N46 $(0,0.4,0.8$ or $1.6 \mathrm{mM})$, was estimated by extrapolating the straight portion of the $\pi$-A isotherm to zero surface pressure.

DCF. CGA-N46 treatment of $C$. krusei cells decreased DCF fluorescence in a concentration-dependent manner (Fig. 4). This result suggests that CGA-N46 is able to reduce the levels of intracellular ROS.

Effects of CGA-N46 on mitochondrial membrane potential. To investigate the effects of CGA-N46 on the mitochondrial membrane potential of $C$. krusei cells, the cells were treated with CGA-N46 $(0,0.2,0.4$ or $0.8 \mathrm{mM})$ for $3 \mathrm{~h}$ at $30^{\circ} \mathrm{C}$. The mitochondrial membrane potential was analyzed using the fluorescent probe Rh-123, and fluorescence microscopy. The Rh-123 fluorescence emitted by CGA-N46-treated $C$. krusei cells decreased in a concentration-dependent manner (Fig. 5). This result suggests that CGA-N46 is able to reduce the mitochondrial membrane potential of C. krusei cells.

Effects of CGA-N46 on DNA synthesis. In order to determine whether CGA-N46 inhibits DNA synthesis, the effects 

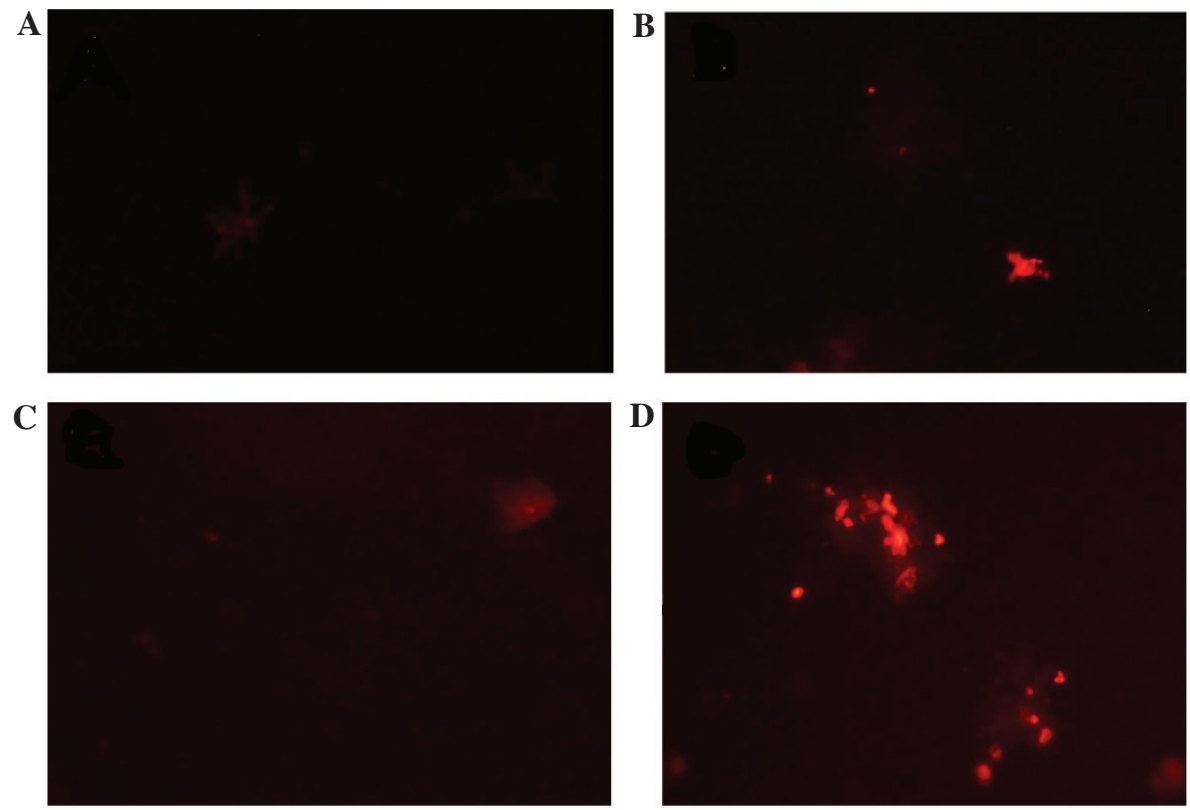

Figure 3. Fluorescent probe propidium iodide detection of the effects of (A) 0 , (B) 0.4 , and (C) $0.8 \mathrm{mM}$ chromogranin A-N46 on the outer membrane permeability of Candida krusei cells. (D) C. krusei cells treated with $0.3 \%$ Triton X-100 as a positive control (magnification, $\mathrm{x} 40$ ).
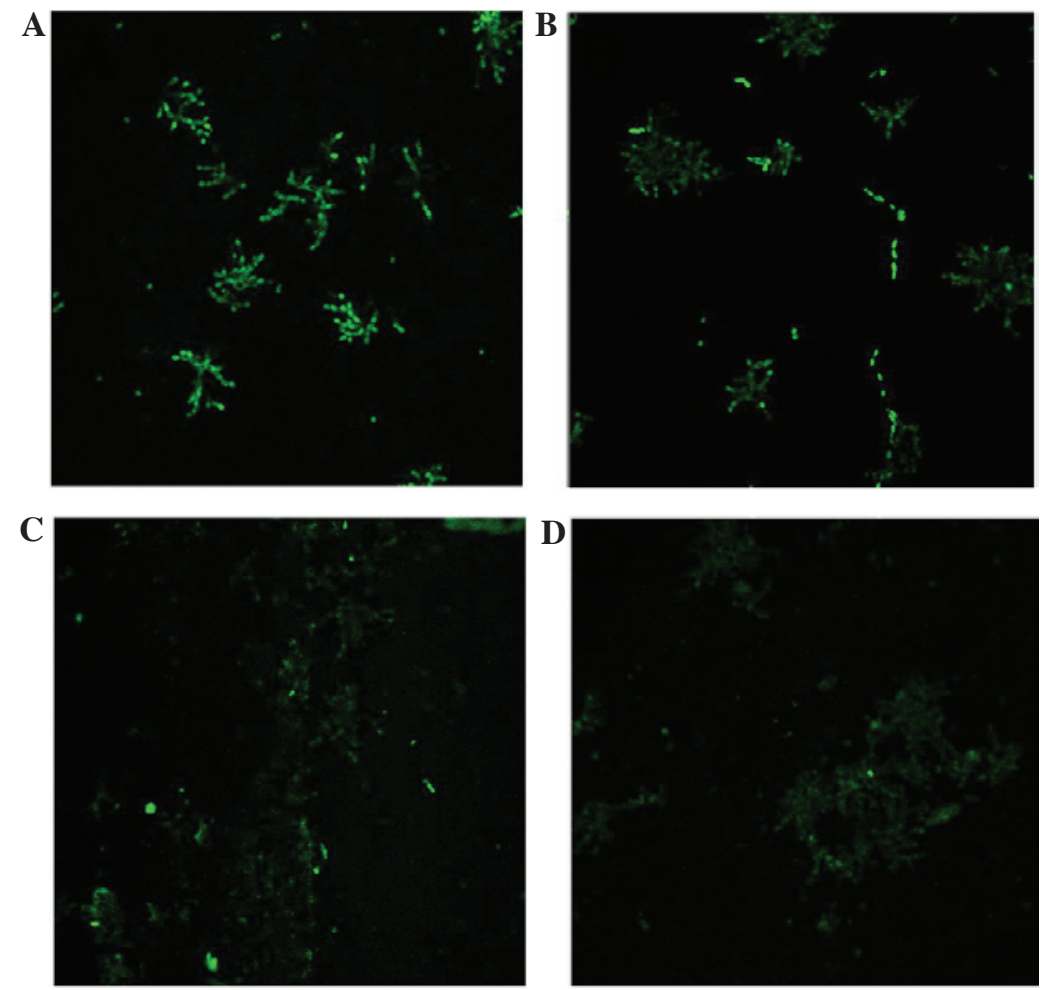

Figure 4. Fluorescent probe 2'-7'-dichlorofluorescin diacetate detection of the levels of intracellular reactive oxygen species in Candida krusei cells following treatment with (A) 0 , (B) 0.2 , (C) 0.4 , and (D) $0.8 \mathrm{mM}$ chromogranin A-N46 for $3 \mathrm{~h}$ at $30^{\circ} \mathrm{C}$ (magnification, $\mathrm{x} 40$ ).

of CGA-N46 on the Taq polymerase in a PCR assay were analyzed. CGA-N46 was incubated with Taq DNA polymerase for $30 \mathrm{~min}$ at $37^{\circ} \mathrm{C}$ prior to $\mathrm{PCR}$, and this was compared to a reaction without prior incubation. The agarose gel electrophoresis separation of the PCR products suggested that, as expected, there was no PCR product when Taq DNA polymerase was absent from the PCR system (Fig. 6, lanes 5 and 6). Furthermore, PCR product was observed when Taq
DNA polymerase was included in the reaction mixture (Fig. 6, lanes 7 and 8); however, there was no PCR product detected when Taq DNA polymerase was treated with CGA-N46 (Fig. 6, lanes 3 and 4). The results suggest that CGA-N46 inactivates the Taq DNA polymerase, thereby inhibiting DNA synthesis.

Effects of CGA-N46 on cell cycle distribution. In order to investigate the effects of CGA-N46 on DNA synthesis in vivo, 

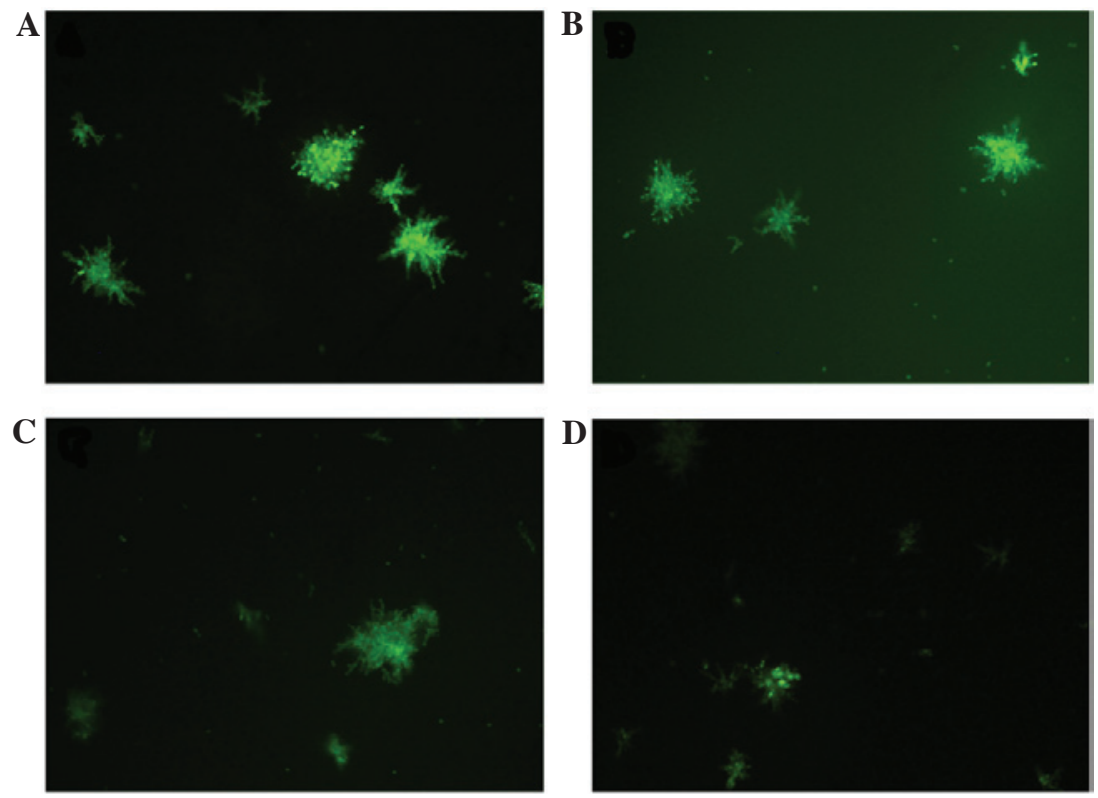

Figure 5. Fluorescent probe Rhodamine-123 detection of the mitochondrial membrane potential in Candida krusei cells treated with (A) 0 , (B) 0.2 , (C) 0.4 and (D) $0.8 \mathrm{mM}$ chromogranin A-N46 for $3 \mathrm{~h}$ at $30^{\circ} \mathrm{C}$ (magnification, $\mathrm{x} 40$ ).

cell cycle and DNA distribution analyses were performed for C. krusei cells treated with $0.8 \mathrm{mM}$ CGA-N46 for 12,24 and $48 \mathrm{~h}$. Following treatment with CGA-N46, the proportion of C. krusei cells in the $\mathrm{G}_{0} / \mathrm{G}_{1}$ phase remained constant (Fig. 7), which indicated that CGA-N46 arrested cell proliferation at the $\mathrm{G}_{0} / \mathrm{G}_{1}$ phase by blocking DNA synthesis. This result is consistent with the in vitro PCR results. In addition, the DNA content in the apoptotic phase significantly increased following treatment with CGA-N46 (cells in the sub- $\mathrm{G}_{0} / \mathrm{G}_{1}$ phase are considered apoptotic) (Fig. 8). However, after $12 \mathrm{~h}$, the DNA content of apoptotic cells decreased, and this was accompanied by an increase in the DNA content of $S$ phase and $\mathrm{G}_{2} / \mathrm{M}$ phase cells. This result indicates that the antagonistic effects of CGA-N46 may be lost by $24 \mathrm{~h}$.

\section{Discussion}

AMPs are widely distributed in nature and have important roles in the host defense against microbial pathogens. Numerous organisms use these peptides as an innate defense mechanism that protects against invading microorganisms (17,37-39); the high cationic charge and strong amphipathic nature of AMPs enables them to bind to the anionic microbial cell membrane and disrupt the membrane bilayer via the formation of pores or channels (39-41), which in turn leads to intracellular potassium ion leakage and cell death (41). As compared with the classical pore-forming peptides, CGA-N46 is a weak alkaline $\alpha$-helical peptide and does not kill Candida spp. via a pore-forming mechanism. Conversely, in the present study, CGA-N46 was transported into the cytoplasm of Candida spp. via a mechanism that disrupted the arrangement of phospholipids in the cell membrane without disturbing its integrity.

Lugardon et al (28) proposed that $\mathrm{N}$-terminal derived fragments of CGA may promote destabilization of the fungal plasma membrane. In the present study, CGA-N46 was able

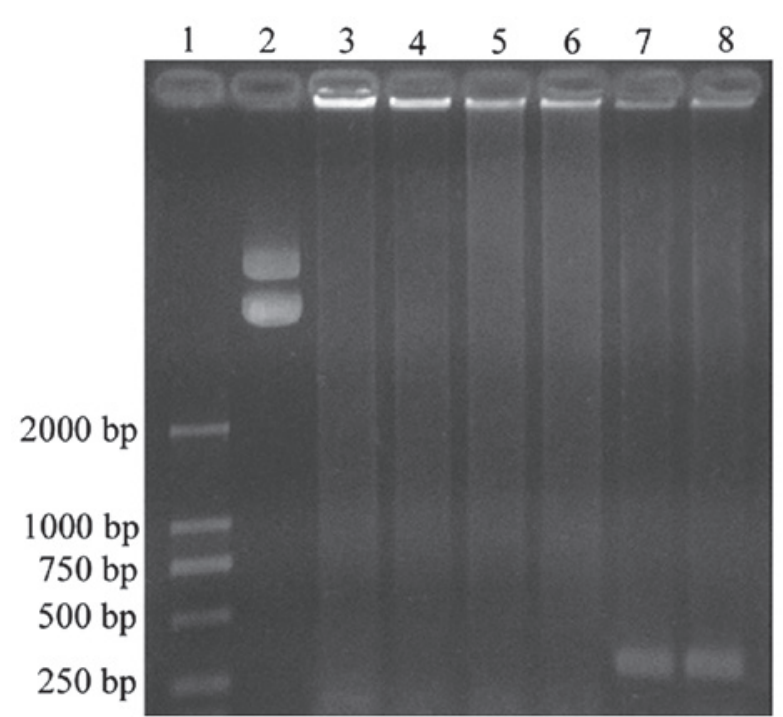

Figure 6. Agarose gel electrophoresis separation of the polymerase chain reaction (PCR) products. Lane 1, DNA Marker; Lane 2, PCR template; Lane 3, Taq DNA polymerase incubated with chromogranin A (CGA)-N46 at $37^{\circ} \mathrm{C}$ for $30 \mathrm{~min}$ prior to adding into the PCR reaction system; Lane 4 Taq DNA polymerase and CGA-N46 were added into the PCR reaction system without prior incubation at $37^{\circ} \mathrm{C}$; Lane 5 , CGA-N46 was incubated at $37^{\circ} \mathrm{C}$ for $30 \mathrm{~min}$ in the absence of Taq DNA polymerase, prior to adding into the PCR system; Lane 6, CGA-N46 was added into the PCR system without Taq DNA polymerase; Lane 7, Taq DNA polymerase was incubated at $37^{\circ} \mathrm{C}$ for $30 \mathrm{~min}$ in the absence of CGA-N46 prior to adding into the PCR system; and Lane 8, Taq DNA polymerase was added into the PCR system without CGA-N46.

to promote the destabilization of a phospholipid monolayer. Numerous antibacterial peptides have been demonstrated to pass through the cell membrane of microbial pathogens, without damaging the membrane integrity; instead they interact with intracellular organelles and macromolecules, and influence intracellular nucleic acid synthesis and repair, protein synthesis, cell wall and membrane synthesis and numerous 

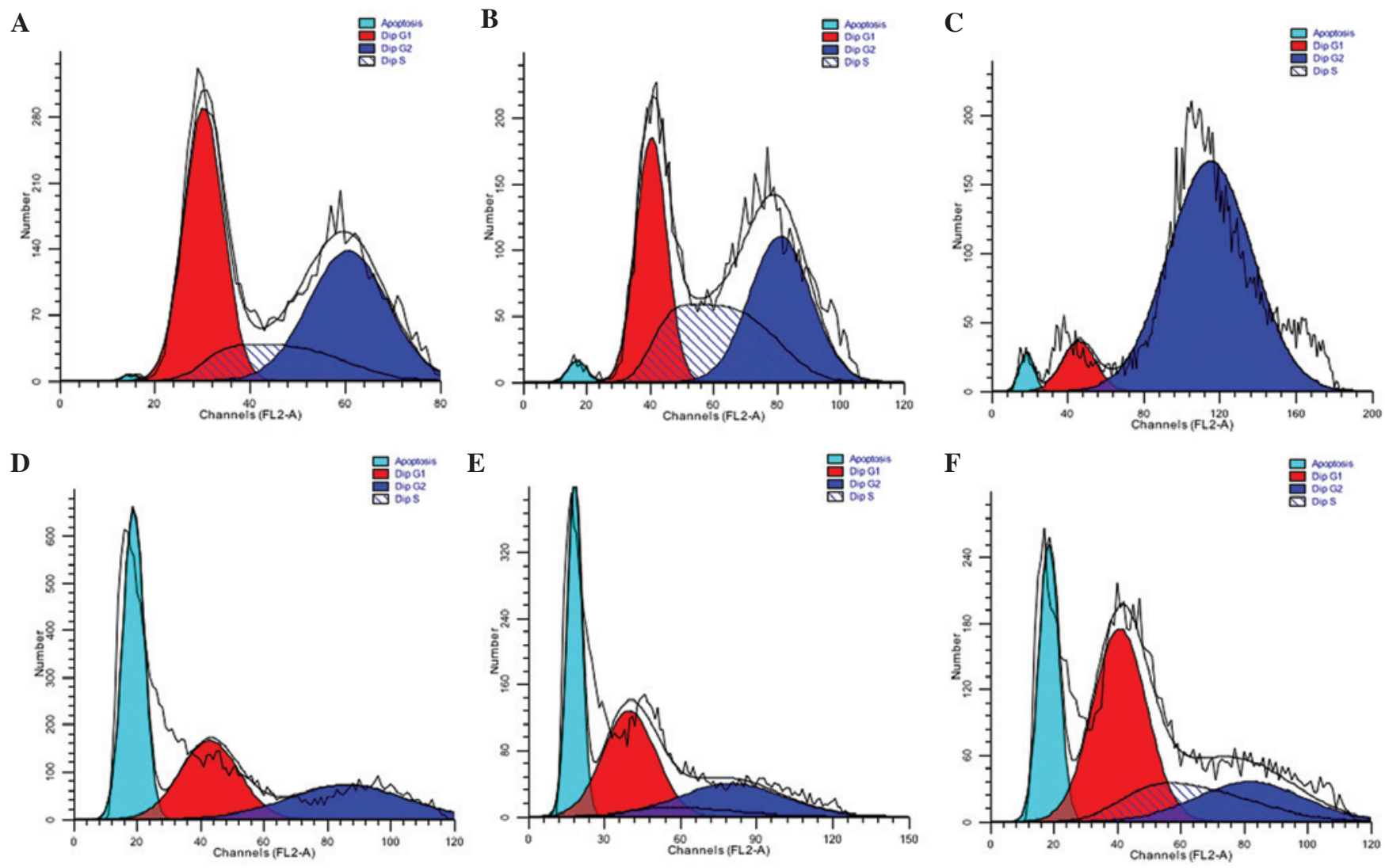

Figure 7. Flow cytometric analysis of Candida krusei cell apoptosis. C. krusei cells incubated in the absence of chromogranin A (CGA)-N46 for (A) 12 , (B) 24 and (C) 48 h. C. krusei cells treated with $0.8 \mathrm{mM}$ of CGA-N46 for (D) 12 , (E) 24 and (F) 48 h. The $\mathrm{G}_{1}$ indicates the $\mathrm{G}_{0 /} \mathrm{G}_{1}$ transition and the $\mathrm{G}_{2}$ indicates $\mathrm{G}_{2} / \mathrm{M}$ transition.

physiological activities $(42,43)$. In a previous study $(40)$, the human salivary antimicrobial peptide Muc7 damaged the fungal mitochondrial membrane, leading to vacuolation of the mitochondria and deformation or degradation of the ridge, thereby resulting in the cell death. These effects were similarly observed in the C. krusei cells treated with CGA-N46 in the present study.

Unlike classical AMPs, CGA-N46 destroyed mitochondrial structure and nuclear envelope integrity, and induced a reduction in the levels of intracellular ROS. An abnormal cellular ROS balance has previously been associated with mitochondrial structural injury (35), and the results of the present study corroborated this. In addition, treatment with CGA-N46 was associated with a decreased mitochondrial membrane potential of $C$. krusei cells. The present study hypothesized that CGA-N46 may disrupt the mitochondrial electron transfer chain by reducing the mitochondrial membrane potential, following the reduction of $\mathrm{O}_{2}{ }^{-}$and $\mathrm{H}_{2} \mathrm{O}_{2}$ generation. The results of the present study align with those reported in Bensassi et al (44), and were also demonstrated in the inhibitory effect of terbinafine, which reduced the ability of $C$. albicans to generate ROS (45).

Numerous antibacterial peptides are able to inhibit replication and transcription by binding to DNA, and this is one example of a mechanism by which AMPs exert their antibacterial activity (46-48). In the present study, a gel retardation assay was performed to determine whether CGA-N46 associated with $C$. krusei DNA. The agarose gel electrophoresis results

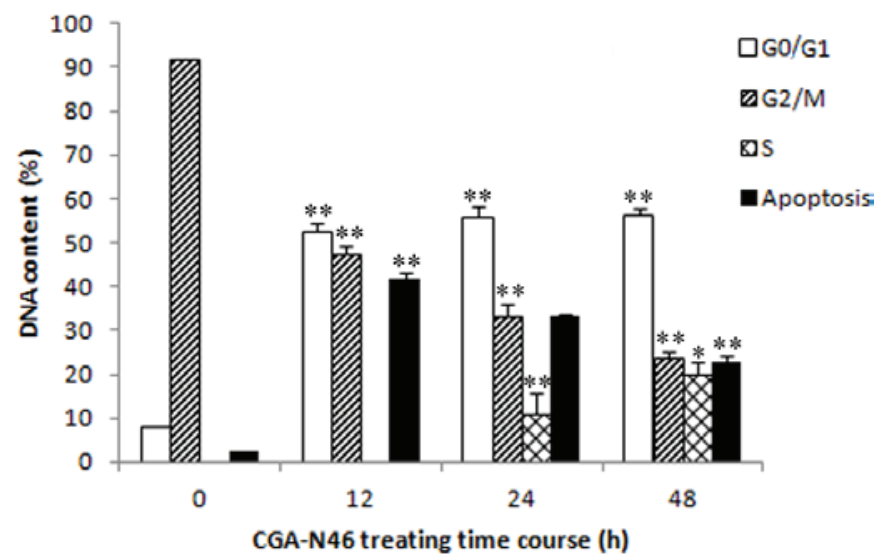

Figure 8. Flow cytometric analysis of the DNA distribution in the cell cycle of Candida krusei cells treated with $0.8 \mathrm{mM}$ chromogranin A-N46 for 12 , 24 and $48 \mathrm{~h}$. Data presented as the mean \pm standard error. ${ }^{* * *} \mathrm{P}<0.01$ vs. control.

demonstrated that the migration of DNA was not retarded following CGA-N46 treatment, even at a weight ratio of 1:80 of CGA-N46 to C. krusei chromosomal DNA (data not shown). This suggested that CGA-N46 did not associate with C. krusei DNA, which may have been due to the near-neutral charge of CGA-N46. The results of the PCR and cell cycle distribution analyses suggested that CGA-N46 was able to inhibit the synthesis of DNA in vitro and in vivo, and the results of the in vitro PCR indicated that CGA-N46 may kill Candida species by inactivating DNA polymerase. 
In conclusion, AMPs have been demonstrated to kill microbes via numerous mechanisms that exert effects on various targets. Concordantly, the CGA-N46 peptide analyzed in the present study exerted its anti-candidal effects on numerous intracellular targets of $C$. krusei cells. Therefore, CGA-N46 may be considered a promising candidate for the treatment of patients with candidiasis.

\section{Acknowledgements}

The authors of the present study would like to thank Mr. Liang Wang, College of Biological Engineering, Henan University of Technology for the flow cytometry analyses. This study was supported by grants from the National Natural Science Foundation of China (grant no. 31071922) and the Henan University of Technology (grant no. 11JCYJ10).

\section{References}

1. Pfaller MA and Diekema DJ: Epidemiology of invasive mycoses in North America. Crit Rev Microbiol 36: 1-53, 2010.

2. Bassetti M, Taramasso L, Nicco E, Molinari MP, Mussap M and Viscoli C: Epidemiology, species distribution, antifungal susceptibility and outcome of nosocomial candidemia in a tertiary care hospital in Italy. PLoS One 6: e24198, 2011.

3. Scorzoni L, de Lucas MP, Mesa-Arango AC, Fusco-Almeida AM, Lozano E, Cuenca-Estrella M, Mendes-Giannini MJ and Zaragoza O: Antifungal efficacy during Candida krusei infection in non-conventional models correlates with the yeast in vitro susceptibility profile. PLoS One 8: e60047, 2013.

4. Shorr AF, Gupta V, Sun X, Johannes RS, Spalding J and Tabak YP: Burden of early-onset candidemia: Analysis of culture-positive bloodstream infections from a large U.S. database. Crit Care Med 37: 2519-2526, 2009.

5. Colombo AL, Tobón A, Restrepo A, Queiroz-Telles F and Nucci M: Epidemiology of endemic systemic fungal infections in Latin America. Med Mycol 49: 785-798, 2011.

6. Pushpanathan M, Rajendhran J, Jayashree S, Sundarakrishnan B, Jayachandran S and Gunasekaran P: Direct cell penetration of the antifungal peptide, MMGP1, in Candida albicans. J Pept Sci 18: 657-660, 2012.

7. Arendrup MC: Epidemiology of invasive candidiasis. Curr Opin Crit Care 16: 445-452, 2010.

8. Leroy O, Gangneux JP, Montravers P, Mira JP, Gouin F, Sollet JP, Carlet J, Reynes J, Rosenheim M, Regnier B and Lortholary O; AmarCand Study Group: Epidemiology, management, and risk factors for death of invasive Candida infections in critical care: A multicenter, prospective, observational study in France (2005-2006). Crit Care Med 37: 1612-1618, 2009.

9. Muñoz P, Sánchez-Somolinos M, Alcalá L, Rodríguez-Créixems M, Peláez T and Bouza E: Candida krusei fungaemia: Antifungal susceptibility and clinical presentation of an uncommon entity during 15 years in a single general hospital. J Antimicrob Chemother 55: 188-193, 2005.

10. Abbas J, Bodey GP, Hanna HA, Mardani M, Girgawy E, Abi-Said D, Whimbey E, Hachem R and Raad I: Candida krusei fungemia. An escalating serious infection in immunocompromised patients. Arch Intern Med 160: 2659-2664, 2000.

11. Bowdish DM, Davidson DJ and Hancock RE: A re-evaluation of the role of host defence peptides in mammalian immunity. Curr Protein Pept Sci 6: 35-51, 2005.

12. Huang J, Hao D, Chen Y, Xu Y, Tan J, Huang Y, Li F and Chen Y: Inhibitory effects and mechanisms of physiological conditions on the activity of enantiomeric forms of an $\alpha$-helical antibacterial peptide against bacteria. Peptides 32: 1488-1495, 2011

13. Teixeira V, Feio MJ and Bastos M: Role of lipids in the interaction of antimicrobial peptides with membranes. Prog Lipid Res 51: 149-177, 2012

14. Lv Y, Wang J, Gao H, Wang Z, Dong N, Ma Q and Shan A: Antimicrobial properties and membrane-active mechanism of a potential $\alpha$-helical antimicrobial derived from cathelicidin PMAP-36. PLoS One 9: e86364, 2014.
15. Auvynet $\mathrm{C}$ and Rosenstein Y: Multifunctional host defense peptides: Antimicrobial peptides, the small yet big players in innate and adaptive immunity. FEBS J 276: 6497-6508, 2009.

16. Shang D, Sun Y, Wang C, Wei S, Ma L and Sun L: Membrane interaction and antibacterial properties of chensinin-1, an antimicrobial peptide with atypical structural features from the skin of Rana chensinensis. Appl Microbiol Biotechnol 96: 1551-1560, 2012.

17. Vila-Farres X, Garcia de la Maria C, López-Rojas R, Pachón J, Giralt E and Vila J: In vitro activity of several antimicrobial peptides against colistin-susceptible and colistin-resistant Acinetobacter baumannii. Clin Microbiol Infect 18: 383-387, 2012.

18. Gopal R, Seo CH, Song PI and Park Y: Effect of repetitive lysine-tryptophan motifs on the bactericidal activity of antimicrobial peptides. Amino Acids 44: 645-660, 2013.

19. Li R, Zhang T, Luo J, Wang F, Gu Q, Gan J and Xiao F: Antifungal activity fragments of $\mathrm{N}$ domain of chromogranin A. Zhong Shan Da Xue Xue 45: 64-67, 2006 (In Chinese).

20. Eiden LE: Is chromogranin a prohormone? Nature 325: 301, 1987.

21. Simon JP and Aunis D: Biochemistry of the chromogranin A protein family. Biochem J 262: 1-13, 1989.

22. Helle KB: Chromogranins: Universal proteins in secretory organelles from paramecium to man. Neurochem Int 17: 165-175, 1990.

23. Lugardon K, Raffner R, Goumon Y, Corti A, Delmas A, Bulet P, Aunis D and Metz-Boutigue MH: Antibacterial and antifungal activities of vasostatin-1, the N-terminal fragment of chromogranin A. J Biol Chem 275: 10745-10753, 2000.

24. Radek KA, Lopez-Garcia B, Hupe M, Niesman IR, Elias PM, Taupenot L, Mahata SK, O'Connor DT and Gallo RL: The neuroendocrine peptide catestatin is a cutaneous antimicrobial and induced in the skin after injury. J Invest Dermatol 128 : $1525-1534,2008$.

25. Akaddar A, Doderer-Lang C, Marzahn MR, Delalande F, Mousli M, Helle K, Van Dorsselaer A, Aunis D, Dunn BM, Metz-Boutigue MH and Candolfi E: Catestatin, an endogenous chromogranin A-derived peptide, inhibits in vitro growth of Plasmodium falciparum. Cell Mol Life Sci 67: 1005-1015, 2010.

26. Mahata SK, Mahata M, Fung MM and O'Connor DT: Catestatin: A multifunctional peptide from chromogranin A. Regul Pept 162: 33-43, 2010.

27. Lugardon K, Chasserot-Golaz S, Kieffer A-E, Maget-Dana R, Nullans G, Kieffer B, Aunis D and Metz-Boutigue MH: Structural and biological characterization of chromofungin, the antifungal chromogranin A-(47-66)-derived peptide. J Biol Chem 276: 35875-35882, 2001.

28. Blois A, Holmsen H, Martino G, Corti A, Metz-Boutigue MH and Helle KB: Interactions of chromogranin A-derived vasostatins and monolayers of phosphatidylserine, phosphatidylcholine and phosphatidylethanolamine. Regul Pept 134: 30-37, 2006.

29. Zasloff M: Antimicrobial peptides of multicellular organisms. Nature 415: 389-395, 2002.

30. Li Y, Xiang Q, Zhang Q, Huang Y and Su Z: Overview on the recent study of antimicrobial peptides: Origins, functions, relative mechanisms and application. Peptides 37: 207-215, 2012.

31. Li R, Lu Y, Chen S, Zhang H, Wang B, Xiong Q: Bioinformatics analysis of animal endogenous peptides CGA-N46. Dong Wu Yi Xue Jin Zhan 34: 43-46, 2013 (In Chinese).

32. Clinical and Laboratory Standards Institute: Reference method for broth dilution antifungal susceptibility testing of yeasts: Approved standard. 3rd edition. CLSI document M27-A3. Clinical and Laboratory Standards Institute, Wayne, PA, USA, 2008.

33. Jurevic RJ, Traboulsi RS, Mukherjee PK, Salata RA and Ghannoum MA; Oral HIV/AIDS Research Alliance Mycology Focus group: Identification of gentian violet concentration that does not stain oral mucosa, possesses anti-candidal activity and is well tolerated. Eur J Clin Microbiol Infect Dis 30: 629-633, 2011.

34. Chen Y, Sun R and Wang B: Monolayer behavior of binary systems of betulinic acid and cardiolipin: Thermodynamic analyses of Langmuir monolayers and AFM study of Langmuir-Blodgett monolayers. J Colloid Interface Sci 353: 294-300, 2011.

35. Li D, Ma H, Ye Y, Ji C, Tang X, Ouyang D, Chen J, Li Y and Ma Y: Deoxynivalenol induces apoptosis in mouse thymic epithelial cells through mitochondria-mediated pathway. Environ Toxicol Pharmacol 38: 163-171, 2014. 
36. Sambrook J and Rusell DW (eds.): Molecular Cloning: A Laboratory Mannual.3rd edition. Cold Spring Harbor Laboratory press, New York, 2001

37. van Kan EJ, Demel RA, van der Bent A and de Kruijff B: The role of the abundant phenylalanines in the mode of action of the antimicrobial peptide clavanin. Biochim Biophys Acta 1615: 84-92, 2003

38. Hancock RE and Scott MG: The role of antimicrobial peptides in animal defenses. Proc Natl Acad Sci USA 97: 8856-8861, 2000.

39. Mochon AB and Liu H: The antimicrobial peptide histatin-5 causes a spatially restricted disruption on the Candida albicans surface, allowing rapid entry of the peptide into the cytoplasm. PLoS Pathog 4: e1000190, 2008.

40. Bobek LA and Situ H: MUC7 20-Mer: Investigation of antimicrobial activity, secondary structure and possible mechanism of antifungal action. Antimicrob Agents Chemother 47: 643-652, 2003.

41. Bolintineanu D, Hazrati E, Davis HT,Lehrer RI and Kaznessis YN: Antimicrobial mechanism of pore-forming protegrin peptides: 100 pores to kill E. coli. Peptides 31: 1-8, 2010.

42. Park CB, Kim HS and Kim SC: Mechanism of action of the antimicrobial peptide buforin II: Buforin II kills microorganisms by penetrating the cell membrane and inhibiting cellular functions. Biochem Biophys Res Commun 244: 253-257, 1998.
43. Kochervinskii VV, Yudin SG, Zanaveskina IS, Arkharova HA, Klechkovskaya VV and Lokshin BV: Structure and appearance of residual polarization in thin films of polyvinylidene fluoride prepared via the Langmuir-Blodgett method. Polym Sci Ser A 52: 40-48, 2010.

44. Bensassi F, Gallerne C, el Dein OS, Hajlaoui MR, Bacha H and Lemaire C: Mechanism of Alternariol monomethyl ether-induced mitochondrial apoptosis in human colon carcinoma cells. Toxicology 290: 230-240, 2011.

45. Sander CS, Hipler UC, Wollina U and Elsner P: Inhibitory effect of terbinafine on reactive oxygen species (ROS) generation by Candida albicans. Mycoses 45: 152-155, 2002.

46. Koshlukova SE, Lloyd TL, Araujo MW and Edgerton M: Salivary histatin 5 induces non-lytic release of ATP from Candida albicans leading to cell death. J Biol Chem 274: 18872-18879, 1999.

47. Moreno AB, Martínez Del Pozo A and San Segundo B: Biotechnologically relevant enzymes and proteins. Antifungal mechanism of the Aspergillus giganteus AFP against the rice blast fungus Magnaporthe grisea. Appl Microbiol Biotechnol 72: 883-895, 2006

48. Zhang J, Wu X and Zhang SQ: Antifungal mechanism of antibacterial peptide, ABP-CM4, from Bombyx mori against Aspergillus niger. Biotechnol Lett 30: 2157-2163, 2008. 